\title{
Membrane technology application in the framework of zero emission concept
}

\begin{abstract}
The Zero emissions concept envisages all industrial inputs being used in final products or converted into value-added inputs for other industries or processes. In this way, industries are reorganized into clusters such that each industry's wastes / by-products are fully matched with the input requirements of another industry, and the integrated whole produces no waste of any kind. This technique is based on the well-established economic analysis tool known as the input/output approach. In the framework of the zero emission concept capture of $\mathrm{CO}_{2}$ plays an important role. $\mathrm{CO}_{2}$ can be captured and permanently stored, or it can be re-used.

Carbon sequestration is a two-step process where the capture of $\mathrm{CO}_{2}$ from a gas stream is followed by its permanent storage. The capture step contributes $75 \%$ to the overall carbon sequestration process cost. For this reason, the scientific community has paid a great attention to the development of new processes for $\mathrm{CO}_{2}$ capture. Currently, there is a wide range of technologies to separate $\mathrm{CO}_{2}$ from gas streams. They are based on different physical and chemical processes including absorption, adsorption, cryogenics and membrane technology. The choice of a suitable technology depends on the characteristics of the flue gas stream and, as a consequence, on the power plant technology. As an alternative to conventional processes for $\mathrm{CO}_{2}$ separation and capture, membrane technology shows great potentiality for $\mathrm{CO}_{2}$ capture owing to its easy applicability, efficiency, flexibility, ability to maintain high $\mathrm{CO}_{2}$ pressure and to perform separations at low energy penalties. CO2-selective membranes allow separation of $\mathrm{CO}_{2}$ from different gas streams, such as: flue gas (post-combustion system), natural gas (natural gas processing) and hydrogen (pre-combustion systems) or oxygen from nitrogen (in an oxyfuel combustion system).

In the framework of zero emission concept, this paper gives an overview and analysis of the types of membranes used and membrane technology application in $\mathrm{CO}_{2}$ capture from the point of cost and energy consumption.
\end{abstract}

Keywords: zero emission, membrane technology, $\mathrm{CO}_{2}$ capture

\section{INTRODUCTION}

Zero Emissions represents a shift from the traditional industrial model in which wastes are considered the norm, to integrated systems in which everything has its use. It advocates an industrial transformation whereby businesses emulate the sustainable cycles found in nature and where society minimizes the load it imposes on the natural resource base and learns to do more with what the earth produces.

The Zero Emissions concept envisages all industrial inputs being used in final products or converted into value-added inputs for other industries or processes. In this way, industries are reorganized into clusters such that each industry's wastes/by-products are fully matched with the input requirements of another industry, and the integrated whole produces no waste of any kind. This technique is based on the well-established economic analysis tool known as the input/output approach.

Author's address: Faculty of Technology, Bulevar cara, Lazara 1, Novi Sad, Serbia

Received for Publication: 11. 02. 2014.

Accepted for Publication: 13. 04. 2014.
From an environmental perspective, the elimination of waste represents the ultimate solution to pollution problems that threaten ecosystems at global, national and local levels. In addition, full use of raw materials, accompanied by a shift towards renewable sources, means that utilization of the earth's resources can be brought back to sustainable levels.

One of the most important cornerstones of a sustainable society consists in an industry that uses zero waste, zero emissions processes. These processes require complete recycling or re-use of all raw and auxiliary materials that are not contained in the final product as well as of all operating materials and energy flows. The goal of this kind of production is to extract only those materials from the natural environment that form part of the final product or of by-products. In addition, a sustainable economy also requires that the whole product life from the extraction of raw materials to the disposal of the product be taken into account. Finally, it will be essential to develop a multitude of innovative services, which would make it unnecessary to own certain products.

Today's ideals in the industry are modern and innovative processes that aim to reduce emissions and waste by an efficient and careful input of raw materials. The necessity of using zero emission 
processes becomes evident if one considers the true costs caused by waste and emissions generated in manufacturing processes. The waste produced has to be purchased in the form of raw materials and has to be accounted for in overall production costs (personnel, equipment, disposal). This demonstrates the great potential for savings, which could be realized through the prevention and recycling of emissions.

The strong anthropogenic increase in the emission of $\mathrm{CO}_{2}$ and the related environmental consequences force the developments in the direction of sustainability and Carbon Capture and Storage (CCS). Fossil fuels are with $86 \%$ the dominant energy source utilized in the world [1]. More than one third of the $\mathrm{CO}_{2}$ emissions come from the combustion of fossil fuels in power plants worldwide [23] and also the emission of $\mathrm{CO}_{2}$ associated with the use of $\mathrm{CH}_{4}$ is more than significant. The combustion of gaseous fuels (e.g. natural gas) accounted for 1521 million metric tons of carbon in 2006 , which equals $18.5 \%$ of the total emissions from fossil fuels [3]. In addition, also the emission of $\mathrm{CO}_{2}$ associated with the exploration and production of natural gas is more than significant [1]. The number of easy accessible, low $\mathrm{CO}_{2}$ containing natural gas sources is only limited, urging the exploration of natural gas sources with high(er) concentrations of $\mathrm{CO}_{2}$.

Next to its environmental impact, $\mathrm{CO}_{2}$ reduces the heating value of the $\mathrm{CH}_{4}$ gas streams in power plants [4]. Due to its acidic character, the presence of $\mathrm{CO}_{2}$ can lead to corrosion in equipment and pipelines. Pipeline specifications for natural gases give a maximum value of $2-5 \%$ for the $\mathrm{CO}_{2}$ content while the $\mathrm{CO}_{2}$ content for liquefied natural gas
(LNG) even needs to be reduced to 50-100 ppm. This makes the removal of $\mathrm{CO}_{2}$ from natural gas of crucial importance. After capturing, the removed $\mathrm{CO}_{2}$ can be reused for different applications in the oil, food and chemical industry. Enhanced oil recovery [1] as well as algae biofixation, where $\mathrm{CO}_{2}$ is used for microalgaes as carbon source, are important applications. Smaller fields of application, like $\mathrm{CO}_{2}$ enrichment in greenhouses, where the increase in $\mathrm{CO} 2$ concentration from $350 \mathrm{ppm}$ to $500 \mathrm{ppm}$ results in a production increase of $25 \%$ for certain bulk crops are of additional interest. Although several possibilities for reuse of $\mathrm{CO}_{2}$ exist, the total capacity of the different options for the reuse of $\mathrm{CO}_{2}$ do not match with the current production and, to reduce the emission of $\mathrm{CO}_{2}$ into the atmosphere, additional storage of $\mathrm{CO}_{2}$ is currently inevitable. Possibilities to store $\mathrm{CO}_{2}$ include ocean sequestrations, geological sequestrations and the sequestrations of $\mathrm{CO}_{2}$ in saline aquifers. In life cycle investigations, Khoo et al.[5] determined the effectiveness of the different $\mathrm{CO}_{2}$ sequestration ways and the potential environmental impact. The results showed geological sequestration methods to be the safest methods with the least environmental burdens.

In coal-based power production usually there are three ways for $\mathrm{CO}_{2}$ capture considered:

1. post-combustion $\mathrm{CO}_{2}$ capture from power plant flue gas,

2. pre-combustion $\mathrm{CO}_{2}$ capture from gasified coal synthesis gas, and

3. oxy-combustion, which separates oxygen from air prior to combustion and produces a nearly sequestration-ready $\mathrm{CO}_{2}$ effluent

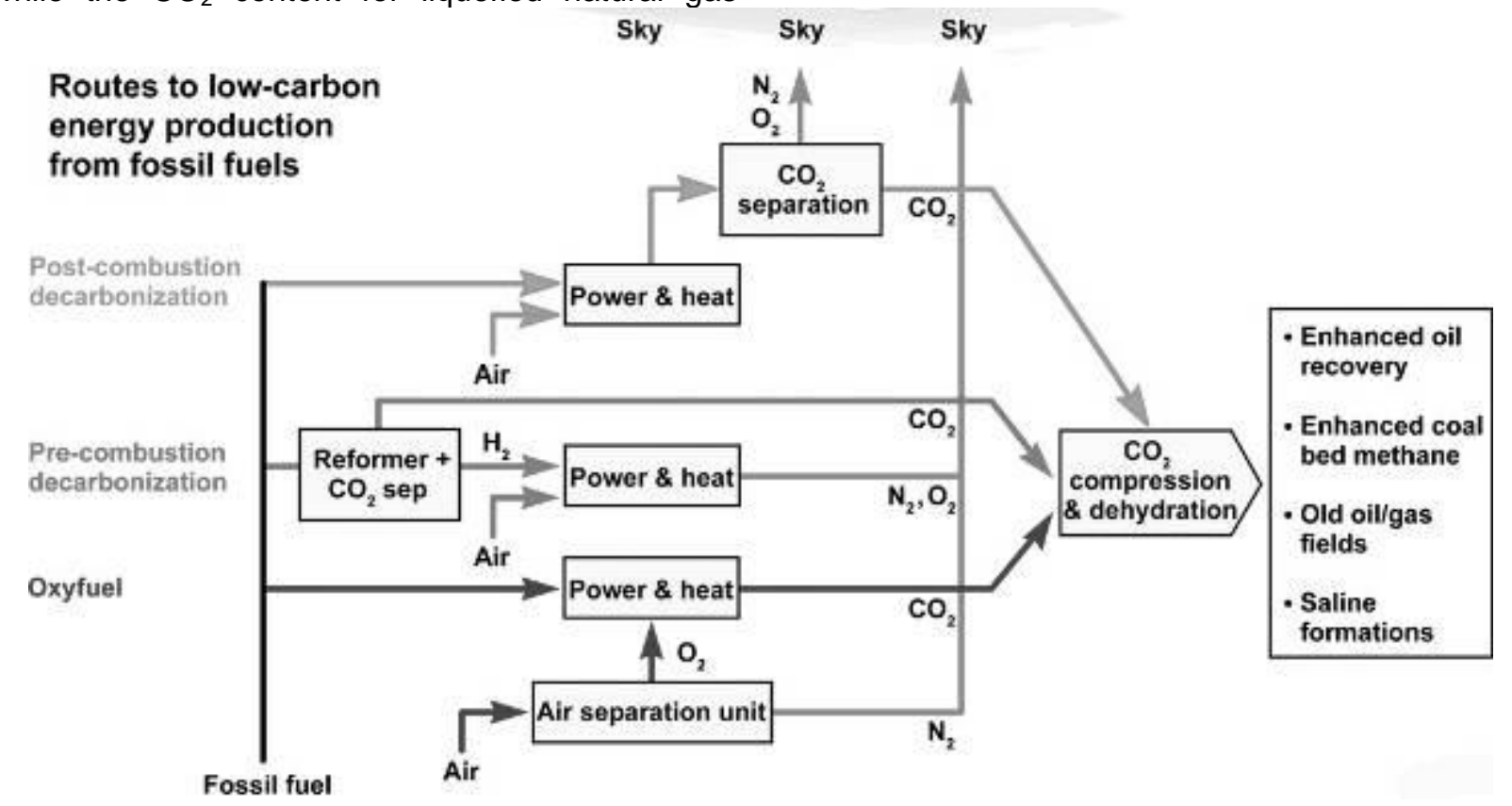

Figure 1 - Approaches to power generation with fossil fuels (coal, oil and natural gas) that include carbon dioxide capture and sequestration (CCS). 


\section{SEPARATION METHODS}

Traditional methods used to separate $\mathrm{CO}_{2}$ from gas mixtures are pressure swing adsorption, cryogenic distillation and the most frequently used method amine absorption. Also membrane processes are frequently used for gas separation. Examples are e.g. the separation of oxygen and nitrogen from air to produce nitrogen enriched air, but also for the separation of $\mathrm{CO}_{2}$ from $\mathrm{CH}_{4}$ [4]. The main limitation of currently existing membranes is the occurrence of severe plasticization of the membrane in the presence of (high) pressure $\mathrm{CO}_{2}$. Due to excessive swelling of the polymer membrane upon exposure to $\mathrm{CO}_{2}$, the performance (selectivity) decreases significantly, thus reducing the purity of the $\mathrm{CO}_{2}$ and consequently reducing the possibilities for reuse of the gas. Energy requirements on the other hand significantly benefit the use of membrane technology over other technologies: membrane technology uses $70-75 \mathrm{kWh}$ per ton of recovered $\mathrm{CO} 2$ compared to significantly higher values for pressure swing adsorption (160$180 \mathrm{kWh})$, cryogenic distillation (600-800 kWh) or amine absorption (330-340 kWh) [5], making membrane technology an attractive alternative.

\section{MEMBRANE TECHNOLOGY}

Membrane technology is an attractive and competitive alternative to conventional absorption technology. It has a high energy efficiency, is easy to scale-up because of its modular design and it has a high area-to-volume ratio. A limitation can be found in the permeability-selectivity tradeoff relation: more permeable membrane materials are generally less selective and vice versa. Since 1980s gas separation with membranes has emerged into a commercially viable method. Nowadays, several hundreds of plants use membrane technology for the separation of gases.

Most plants use cellulose-acetate membranes, which have $\mathrm{CO}_{2} / \mathrm{CH}_{4}$ selectivities of only 15 According to Baker $[6,7]$, the competiveness of membranes for the separation of $\mathrm{CO}_{2} / \mathrm{CH}_{4}$ would strongly increase if stable membranes with a selectivity of 40 during operation would become available. Due to plasticization in the presence of $\mathrm{CO}_{2}$, membranes often lose their performance at elevated pressure. Swelling stresses on the polymer network and an increase in free volume and segmental mobility upon exposure to $\mathrm{CO}_{2}$ cause a rise in permeability for all components, and especially the permeability of the low permeating component, consequently resulting in a decrease in selectivity [7]. The development of polymeric membranes and membrane processes with improved plasticization resistance that maintain selectivity and permeability, even at higher $\mathrm{CO}_{2}$ partial feed pressures is crucial and an important field of research.

\section{MEMBRANE MODULES FOR $\mathrm{CO}_{2}$ SEQUESTRATION}

Conventionally, the membrane must be packed in a proper device called a 'membrane module', which should offer:

- low production costs

- high packing density

- low energy consumption

- good control of concentration polarization.

For the application of the membranes in gas separation processes, several confi gurations are conventionally used for the membrane housing such as hollow and capillary fi bre systems and spiral wounds.

It should be stated that the commercial membrane modules available today are specifi cally designed for a specifi c membrane process application. However, the choice of a module configuration depends on:

- type of separation problem

- ease of cleaning

- ease of maintenance

- ease of operation

- compactness of the system

- scale

- possibility of membrane replacement.

\section{MODULES BASED ON HOLLOW FIBRE MEMBRANES}

Hollow fi bre membranes are made from extremely thin polymeric tubes, with a diameter of 50 $200 \mu \mathrm{m}$ [8]. The selective layer is on the outside surface of the fi bres, facing the high-pressure gas. A hollow fibre membrane module normally contains tens of thousands of parallel fi bres deposited at both ends in epoxy tube sheets [8]. These kinds of membrane play an important role in gas separation owing to their high separation area and selectivity. Hollow fi bres are stable and show high fl ux with moderate selectivity in a full scale system. The high $\mathrm{fl}$ ux of hollow fi bres is due to the combination of high transfer or separation areas and a thin membrane wall.Moreover, they also possess a low surface energy.

\section{MODULES BASED ON CAPILLARY FIBRE MEMBRANES}

Capillary fi bres are produced using similar equipment to hollow fi bres, but they have a larger diameter, typically, 200-400 $\mu \mathrm{m}[8,9]$. The selective layer is formed on the inside surface of the $\mathrm{fi}$ bres. The free ends of the capillaries are potted agents such as epoxy resins, polyurethanes. In a capillary fi bre module, the feed gas $\mathrm{fl}$ ows through the bore of the fibres.

The pressure difference feed-to-permeate, which capillary fi bres can support, is limited and typically it does not exceed 10-15 bar. Higher 
pressures may rupture fi bres and even a single defective fi bre can seriously degrade the separation capability of the module. Capillary embrane modules are not as expensive or compact as hollow fi bre modules, but they are still very economical. Their principal drawback is the pressure that the fibres can support. This limitation means capillary modules cannot be used at the high pressures that are necessary for hydrogen or natural-gas processing applications [9].

\section{SPIRAL WOUND MODULES}

Generally, sheets of membrane 1-2 m long are cut and folded and then packaged as spiral wound modules [10]. A single module may contain as many as 30 membranes. Spiral wound elements are generally the most economical to operate .

Spiral systems are:

- Compact - high membrane packing density results in more effi cient utilization of $\mathrm{fl}$ oor space;

- Energy efficient - lower power consumption compared to other membrane confi gurations;

- Lower capital cost, when extensive feed pretreatment is not required;

- Robust - high pressure spiral elements can withstand pressures in excess of 1000 psi (6.89 MPa).

\section{COMPARISON BETWEEN DIFFERENT MEMBRANE MODULES}

It is diffi cult to quantify correctly the cost of a module because the same module design varies widely depending on the application considered. Generally, hollow fi bre modules are cheaper than the others even if they are produced for very highvolume applications in order to justify the expense of developing and building the spinning and module fabrication equipment.

Hollow-fi bre and spiral-wound modules are very common mainly owing to their higher area to volume ratio. Spiral-wound modules have distinct advantages over the hollow-fi bre elements in important applications, although the latter can offer higher packing density.

\section{DESIGN FOR POWER PLANT INTEGRATION}

The design of power stations requires simultaneous consideration of heat integration and power generation. Simulation models for gas separation membranes have to consider, generally, an equation describing the gas transport across the membrane, a mass balance equation for each component of the gas mixture, the pressure drops occurring on both sides of the membrane and the boundary conditions [11] The major impediment to the engineering analysis of membrane processes in $\mathrm{CO}_{2}$ separation is the large number and range of process variables. The mixture is often treated as a binary system (generally $\mathrm{CO}_{2}$ and $\mathrm{H}_{2}$ ) and, there- fore, the role of impurities (water, $\mathrm{SO}_{2}, \mathrm{NO}_{\mathrm{x}}$, particles, etc.) has not yet been investigated in detail. Another common assumption is that the constant feed mixture temperature is either close to or slightly above ambient temperature (e.g. $40^{\circ} \mathrm{C}$ ). Moreover, the most important parameter, that must be considered, is the effi ciency of a membrane separation process. The effi ciency depends on three major variables:

- the membrane selectivity

- the pressure ratio between feed and permeate streams;

- the stage cut, the ratio of permeate flow rate to feed flow rate.

Particular attention is paid to the calculation of the $\mathrm{CO}_{2}$ recovery ratio, the fraction of $\mathrm{CO}_{2}$ in the feed captured in the permeate side:

$$
R=\theta \frac{y_{p}}{y_{\text {in }}}
$$

where $y_{\mathrm{p}}$ is the mole fraction of $\mathrm{CO}_{2}$ in the permeate and $x_{\text {in }}$ is the mole fraction of $\mathrm{CO}_{2}$ in the feed. In general, an increase in $\theta$ (and so an increase of the membrane area) is not linear with the recovery of $\mathrm{CO}_{2}$. For this reason, in a problem like $\mathrm{CO}_{2}$ capture, one major objective of scientific studies is to determine the relationship between the $\mathrm{CO}_{2}$ recovery ratio $(R)$ and the corresponding permeate composition $\left(y_{p}\right)$.

The International Energy Agency (IEA) guidelines require $R$ to be above $80 \%$ or $90 \%$ (Davison and Thambimuthu, 2004), because values below this do not offer a suffi cient decrease in $\mathrm{CO}_{2}$ released to the atmosphere. The permeate $\mathrm{CO}_{2}$ mole fraction $y_{p}$ must also be in the range $0.8-0.95$, both to minimize the compression and transportation costs [12] and to prevent problems related to deep ocean or geological disposal. Unfortunately, the recovery ratio $R$ and permeate composition yp seem to be inversely related, such that an increase in $R$ implies a decrease in $y_{p}$ and vice versa.

\section{COST CONSIDERATIONS AND MEMBRANE TECHNOLOGY AT THE INDUSTRIAL SCALE}

Economic analysis includes not only the costs for capture, but also the costs of injection and storage into a geological site, allowing a full comparison processes depend on the fi xed charges and the repayment of the plant investment cost and of operating costs (energy, membrane replacement, maintenance).

In particular, quantitative analysis of the costs strongly depends on the specifi $c$ application, plant and location as well as on the characteristics of membranes and modules. In fact, the costs of capture using gas separation membrane systems can be reduced by increasing the membrane permeability and selectivity.

Improvements in the permeability reduce the capture cost because less membrane area is required for the same $\mathrm{CO}_{2}$ recovery rate. By increasing 
the $\mathrm{CO}_{2} / \mathrm{N}_{2}$ selectivity, the mole fraction of $\mathrm{CO}_{2}$ in the permeate increases. As the capture cost includes the compression of $\mathrm{CO}_{2}$ after separation, a higher $\mathrm{CO}_{2}$ fraction in the permeate stream requires less compression and, thus, less energy; therefore, both the capital expenditure and operating costs are lower.

In contrast, the cost of membranes affects only marginally the capture costs [13]. Therefore, reductions in membrane costs will improve the overall competitiveness of gas separation membrane systems slightly.

Another important aspect of $\mathrm{CO}_{2}$ separation costs is the driving force, which, by using embrane technology, depends on the partial pressure difference between both sides of the membrane. By increasing the pressure across the membrane or reducing the feed gas pressure, the capture cost decreases.

This is because a lower feed pressure requires a smaller compressor, thereby reducing both the capital costs and the total energy consumption [13]. Nevertheless, decreasing the feed pressure, the driving force across the membrane decreases. Therefore, to obtain the same $\mathrm{CO}_{2}$ recovery from the feed gas, the membrane area required must increase. Globally, it is better to increase the costs of the membrane than to use a bigger compressor.

Moreover, just to give a very brief overview of the work in $\mathrm{CO}_{2}$ capture direction, some European projects (in the UE FP6 and FP7 only) are reported in the following:

- Innovative $\mathrm{CO}_{2}$ capture (iCap: 2010-2013). This project is coordinated by the Norwegian University of Science and Technology. The aim of the project is to develop breakthrough technologies that can be applied to post-combustion $\mathrm{CO}_{2}$ capture. These technologies include the use of phase change solvents, the combination of $\mathrm{SO}_{2}$ and $\mathrm{CO}_{2}$ absorption, the use of $\mathrm{CO}_{2}$-selective low-temperature membranes and the development of new energy production cycles with $\mathrm{CO}_{2}$ capture.

- $\mathrm{CO}_{2}$ enhanced separation and recovery (CESAR: 2008-2011. For: CESAR: http://www. co2cesar.eu/index.php). This aims for a breakthrough in the development of low-cost postcombustion $\mathrm{CO}_{2}$ capture technology in order to provide an economically feasible solution for both new large scale power plants and retrofi $t$ of existing power plants. For this project, the research is charged with the development of new membrane contactors, development carried out by SME Polymem and ENSIC-Nancy.

- Nanoglowa is a project based on $\mathrm{CO}_{2}$ capture trough nanostructured membranes (http://www. nanoglowa.com). In this project, the application of nanostructured membranes for $\mathrm{CO}_{2}$ capture and separation brings down the energy penalty related to conventional absorption with amines.

\section{CONCLUSIONS}

Membrane-based technology has several advantages over conventional separation approaches for $\mathrm{CO}_{2}$ capture, such as:

- lower capital cost

- ease of skid-mounted installation

- lower energy consumption

- ability to be applied in remote areas, especially offshore flexibility.

Nevertheless, there are many relevant factors determining the appropriateness of each membrane type for each specifi $c$ application. When selecting a suitable membrane for $\mathrm{CO}_{2}$ separation, the operating temperature and pressure are of paramount importance since they directly affect the separation performance of the membrane. In addition, the composition of the gas mixture to be separated, the material and fabrication costs of the membranes as well as the overall process design need to be taken into account. Moreover, the energy reduction required and the corresponding costs must be addressed. Currently, chemical modification of polymeric membranes is one of the most promising approaches for greatly enhancing separation performance. Therefore, further development of existing modification methods (e.g. identifying better cross-linking agents) or the invention of new modification techniques for existing gas-separation materials may accelerate the commercialization of polymeric membranes for $\mathrm{CO}_{2}$ separation. However, long term stability and performance of polymeric membranes at elevated temperatures are necessary to maintain the robustness of the membranebased systems. In addition to membrane materials selection, membrane configuration and module design are important considerations for industrial applications.

Membrane separation is an attractive and promising technology, which can be applied in combination in all types of power plants. Nevertheless, although membrane technology is widely applied for gas separation, it is not yet used on the scale of power plants. For this reason, a potential objective could be the development of innovative membranebased technologies capable of reducing the cost of $\mathrm{CO}_{2}$ capture, producing, for example, hydrogen from natural gas fuel. This could be, for example, obtained by producing higher selective membranes, such as hybrid membrane-absorbent (or solvent) systems, which use very high surface area to volume ratios for mass exchange between a gas stream and a solvent, resulting in a very compact system. Overall, even though the separation of $\mathrm{CO}_{2}$ using polymer-based membranes is a complex undertaking, it is necessary to address the challenges and continue approaches that will produce the next generation of high performance membranes. 


\section{REFERENCES}

[1] Ipcc, (2005). Special report on carbon dioxide capture and storage: (England), C.U.P.C.

[2] Zhang, H.-Y., Wang, R., Liang, D.T. \& Tay, J.H., (2006). Modeling and experimental study of $\mathrm{CO}_{2}$ absorption in a hollow fiber membrane contactor. Journal of Membrane Science, 279 (1-2), 301-310 ; lea, (2009). $\mathrm{CO}_{2}$ emissions from fuel combustion 1971-2007.

[3] Boden, T.A., Marland, G. \& Andres, R.J., (2010). Global, regional and national fossil-fuel $\mathrm{CO}_{2}$ emissions. Oak Ridge, Tenn., U.S.A.

[4] Simons, K., (2010). Membrane technologies for $\mathrm{CO}_{2}$ capture. PhD Thesis. University of Twente, The Netherlands.

[5] Khoo, H.H. \& Tan, R.B.H., (2006). Life cycle investigation of $\mathrm{CO}_{2}$ recovery and sequestration. Environmental Science and Technology, 40

[6] Baker, R.W., (2002). Future directions of membrane gas separation technology. Industrial \& Engineering Chemistry Research, 41, 1393-1411

[7] Simons, K., Nijmeijer, K., Bara, J.E., Noble, R.D. \& Wessling, M., (2010). How do polymerized roomtemperature ionic liquid membranes plasticize during high pressure $\mathrm{CO}_{2}$ permeation; Journal of Membrane Science, 360 (1-2), 202-209

[8] Baker, R.W. ed. (2004). Membrane technology and applications, Chichester, UK: John Wiley and Sons.

[9] Buysse, C., Kovalevsky, A., Snijkers, F., Buekenhoudt, A., Mullens, S., Luyten, J., Kretzschmar, J. \&
Lenaerts, S., (2010). Fabrication and oxygen permeability of gastight, macrovoid-free ba0.5sr0. $5 c 00.8 f e 0.203-\delta$ capillaries for high temperature gas separation. Journal of Membrane Science, 359 (1-2), 86-92

[10] Lababidi, H., Al-Enezi, G.A. \& M, H.M.E.H., (1996). Optimization of module configuration in membrane gas separation. Journal of Membrane Science, 112 (185-97)

[11] Safari, M., Ghanizadeh, A. \& Montazer-Rahmati, M., (2009). Optimization of membrane based $\mathrm{CO}_{2}$ removal from natural gas using simple models considering both pressure and temperature effects Int J Greenhouse Gas Control,, 3, 3-10 ; Ahmad, F., Lau, K.K. \& Shariff, A.M., (2010). Removal of $\mathrm{CO}_{2}$ from natural gas using membrane separation system: Modeling and process design. Journal of Applied Science, 10, 1134-9. ; Hwang, S.T. \& Kammermeyer, K., Membranes in Separation Techniques of chemistry. 1975 New York: Wiley Interscience.

[12] Davison, J. \& Thambimuthu, K., Year. Technologies for capture of carbon dioxideed.^eds. 7th Greenhouse Gas Technology Conference, Vancouver, Canada.

[13] Ho, M.T., Allinson, G. \& Wiley, D.E., (2006). Comparison of $\mathrm{CO}_{2}$ separation options for geosequestration: Are membranes competitive? Desalination, 192, 288-95

\section{IZVOD}

\section{PRIMENA MEMBRANSKE TEHNOLOGIJE U OKVIRU POJMA NULTE EMISIJE}

Koncept nulte emisije predviđa sve industrijske inpute koji se koriste u finalnoj proizvodnji ili pretvorene $u$ inpute koji ulaze u dodatnu vrednost za druge industrije ili procese. Na ovaj način, industrije se reorganizuju u klastere tako da se otpad svake industrije, sporedni proizvod, u potpunosti poklapa sa ulaznim zahtevima drugih industrije, a integrisana celina ne proizvodi otpad bilo koje vrste. Ova tehnika se zasniva na dobro utvrđenim ekonomskim analizama alata poznatim kao ulazno / izlazni pristupi . U okviru koncepta nulte emisije hvatanje $\mathrm{CO}_{2}$ igra važnu ulogu. $\mathrm{CO}_{2}$ se može uhvatiti i trajno čuvati, ili se može ponovo koristiti.

Sekvestracija ugljenika je proces u dva koraka, gde je hvatanje $\mathrm{CO}_{2}$ iz gasne struje praćeno njegovim stalnim skladištenjem. Proces prikupljanja doprinosi $75 \%$ na ukupne troškove proces zaplena ugljena. Iz tog razloga, naučna zajednica je posvetila veliku pažnju razvoju novih procesa za prikupljanje $\mathrm{CO}_{2}$. Trenutno, postoji širok spektar tehnologija za separaciju $\mathrm{CO}_{2}$ iz gasnih struja. Oni su zasnovani na različitim fizičkim i hemijskim procesima, uključujući apsorpcije, adsorpciji i membranske tehnologije. Izbor odgovarajuće tehnologije zavisi od karakteristika protoka dimnih gasova i, kao posledica toga, na tehnologiji elektrane. Kao alternativa konvencionalnim procesima za separaciju i hvatanje $\mathrm{CO}_{2}$, membranska tehnologija pokazuje veliki potencijal za $\mathrm{CO}_{2}$ zbog njegove lakoća postavljanja, efikasnost, fleksibilnost, mogućnost održavanja visokog pritiska $\mathrm{CO}_{2}$ i obavljanja razdvajanja na niskim vrednostima energije. $\mathrm{CO}_{2}$ - selektivna membrana dozvoljava odvajanje $\mathrm{CO}_{2}$ iz različitih gasnih struja, kao što su: dimnih gasova ( sistem posle sagorevanja), prirodni gas ( prerada prirodnog gasa) i vodonika ( sistemi pre sagorevanja ) ili kiseonika od azota ( u sistemu "oksifuel" sagorevanje).

$U$ okviru koncepta nulte emisije, ovaj rad daje pregled $i$ analizu vrsta membrana koje se koriste $i$ primenjenih membranskih tehnologija za prihvatanje $\mathrm{CO}_{2}$ sa stanovišta troškova i energetske potrošnje.

Ključne reči: nulta emisija, membranska tehnologija, prihvatanje $\mathrm{CO}_{2}$

Originalni naučni rad

Primljeno za publikovanje: 11. 02. 2014.

Prihvaćeno za publikovanje: 13. 04. 2014. 